\title{
Streptomyces hebeiensis sp. nov.
}

\section{Correspondence Cheng-Lin Jiang lihxu@ynu.edu.cn or liact@hotmail.com}

\author{
Ping $\mathrm{Xu},{ }^{1,2}$ Wen-Jun Li, ${ }^{1}$ Wen-long Wu, ${ }^{1}$ Dong Wang, ${ }^{1}$ Li-Hua Xu ${ }^{1}$ \\ and Cheng-Lin Jiang ${ }^{1}$
}

\author{
${ }^{1}$ The Key Laboratory for Microbial Resources of Ministry of Education, Yunnan Institute of \\ Microbiology, Yunnan University, Kunming, Yunnan, 650091, PR China \\ ${ }^{2}$ New Drug R \& D, North China Pharmaceutic Corp., Shijiazhuang, 050015, PR China
}

The genus Streptomyces was proposed by Waksman \& Henrici (1943) for aerobic, spore-forming actinomycetes. Members of Streptomyces are a rich source of bioactive compounds, notably antibiotics, enzymes, enzyme inhibitors and pharmacologically active agents (Bérdy, 1995; Chun et al., 1997; Labeda et al., 1997). In the course of our screening programme for new antibiotics, several actinomycete strains that contained both type-I and type-II polyketide biosynthesis pathway genes were isolated from soil samples collected from Hebei province of China.

Strain YIM $001^{\mathrm{T}}$ was isolated from a soil sample after 2 weeks incubation at $28^{\circ} \mathrm{C}$ on glycerol-asparagine agar [International Streptomyces Project (ISP) medium 5; Shirling \& Gottlieb, 1966]. Biomass for molecular systematic and most of the chemotaxonomic studies was obtained after incubation at $28^{\circ} \mathrm{C}$ for 3 days by growing in shake flasks of ISP 2 broth supplemented with the vitamin mixture of HV medium (Hayakawa \& Nonomura, 1987). Cultural characteristics were determined after 2 weeks at $28^{\circ} \mathrm{C}$ by methods used in the ISP (Shirling \& Gottlieb, 1966). Morphological observations of spores and mycelia were made by light microscopy (Olympus microscope $\mathrm{BH}-2$ ) and scanning electron microscopy (model EPMA-8705).

Abbreviations: $\mathrm{A}_{2} \mathrm{pm}$, diaminopimelic acid; ISP, International Streptomyces Project.

The GenBank/EMBL/DDBJ accession number for the 16S rDNA sequence of strain YIM $001^{\top}$ is $A Y 277529$.

$16 S$ rDNA variable $\gamma$-region and full $16 S$ rDNA sequence similarities are available as supplementary material in IJSEM Online.
The test strain was examined for a range of phenotypic properties using standard procedures (Shirling \& Gottlieb, 1966; Williams et al., 1983). In addition, acid production from carbohydrates was assessed using media and methods described by Gordon et al. (1974). Tolerance of temperature $\left(10,27,30,37\right.$ and $\left.45^{\circ} \mathrm{C}\right)$, sodium chloride $(4,7,10$ and $13 \%)$ and phenol $(0 \cdot 1,0 \cdot 2,0 \cdot 5$ and $1 \cdot 0 \%)$ was tested using modified Bennett's agar (Williams et al., 1983). Colours and hues were determined according to colour chips from the ISCC-NBS Color Charts standard samples no. 2106 (Kelly, 1964).

Cell wells were purified and amino acids of peptidoglycan were analysed by TLC (Lechevalier \& Lechevalier, 1980; Jiang et al., 2001). Analysis of whole-cell sugar composition followed procedures described by Becker et al. (1965) and Lechevalier \& Lechevalier (1980). Phospholipid analysis was carried out as described by Lechevalier et al. (1981). Menaquinones were determined using the procedures of Collins et al. (1977).

Genomic DNA was extracted and 16S rDNA amplified as described by Cui et al. (2001). The DNA G + C base content of strain YIM $001^{\mathrm{T}}$ was determined by the thermal denaturation method (Mandel \& Marmur, 1968). The variable $\gamma$ region (positions 158-277) of the 16S rDNA from 379 known Streptomyces species obtained from the DDBJ databases and strain YIM $001^{\mathrm{T}}$ were aligned. The nearly complete resultant $16 \mathrm{~S}$ rDNA sequence (1520 nucleotides) was aligned manually with corresponding almost-complete sequences of representative Streptomyces species retrieved 
from DDBJ, EMBL and GenBank by using BLAST (Altschul et al., 1997) and BLAST 2 Sequences (Tatusova \& Madden, 1999). CLUSTAL W (Thompson et al., 1994) was used to estimate evolutionary distances (the $K_{\text {nuc }}$ value of Kimura, 1980) and similarity values were used to reconstruct the phylogenetic tree by the neighbour-joining method (Saitou \& Nei, 1987). The topology of the tree was evaluated by performing a bootstrap analysis (Felsenstein, 1985) using 1000 resamplings. Actinoplanes philippinensis (GenBank/ EMBL/DDBJ accession no. D85474) was used as an outgroup. DNA-DNA hybridization experiments using strain YIM $001^{\mathrm{T}}$ and comparative strains were carried out according to the thermal renaturation method (De Ley et al., 1970; Huß et al., 1983).

Strain YIM $001^{\mathrm{T}}$ developed well on several media including ISP 2, ISP 4, potato agar and Czapek's agar and showed moderate growth on ISP 3 , ISP 5 and nutrient agar (Table 1). Diffusible pigments were produced on all media tested. The pigment $(s)$ is not a $\mathrm{pH}$ indicator or changed only slightly with addition of $0.05 \mathrm{M} \mathrm{HCl}$ in ISP 5 and ISP 6. Morphological features were observed on ISP 2, ISP 4 and ISP 5. Aerial mycelium and substrate mycelium were well developed (Fig. 1). At maturity, the aerial mycelium formed long, straight to Rectiflexibiles spore chains. The spores were non-motile. The physiological features are indicated in Table 2 and in the species description. Strain YIM $001^{\mathrm{T}}$ contained LL-diaminopimelic acid $\left(\mathrm{A}_{2} \mathrm{pm}\right)$ and trace amounts of meso- $\mathrm{A}_{2} \mathrm{pm}$. Whole-cell hydrolysates contained mainly glucose and small quantities of xylose, galactose and arabinose. The menaquinones were MK-9 $\left(\mathrm{H}_{4}\right)(4 \cdot 6 \%)$, MK-9 $\left(\mathrm{H}_{6}\right)(60 \%)$, MK-9 $\left(\mathrm{H}_{8}\right)(30 \cdot 7 \%)$ and MK-9 $\left(\mathrm{H}_{10}\right)(4 \cdot 7 \%)$ and the diagnostic phospholipid was phosphatidylethanolamine. The $\mathrm{G}+\mathrm{C}$ content of the DNA was $71.4 \mathrm{~mol} \%$. The chemical and morphological properties of strain YIM $001^{\mathrm{T}}$, except for the detection of a small amount of the menaquinone MK- $9\left(\mathrm{H}_{10}\right)$, are clearly consistent with its assignment to the genus Streptomyces (Williams et al., 1989).

Analysis of $\gamma$-region sequences showed that strain YIM $001^{\mathrm{T}}$ was grouped into a branch with Streptomyces beijiangensis YIM $6^{\mathrm{T}}$ (the nearest neighbour; $93.3 \%$ similarity,

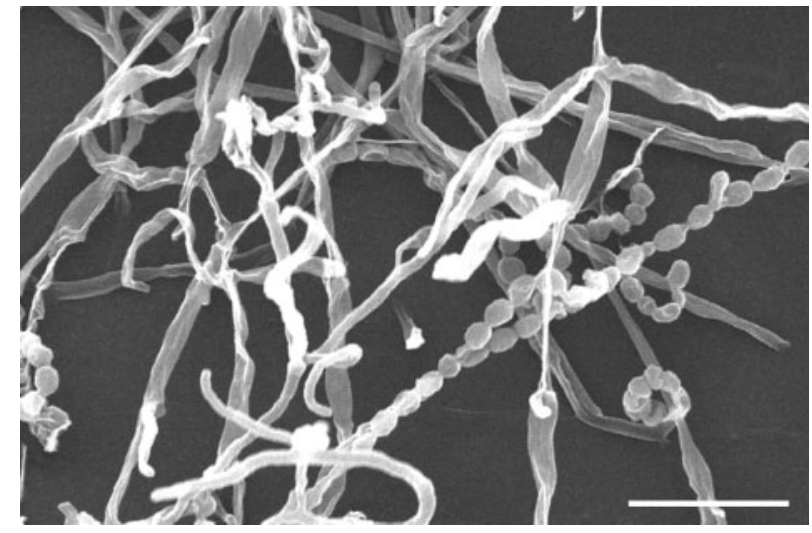

Fig. 1. Scanning electron micrograph of spore chains of Streptomyces hebeiensis sp. nov. YIM $001^{\top}$ grown on yeastmalt extract agar (ISP 2) for 14 days at $28^{\circ} \mathrm{C}$. Bar, $5 \mu \mathrm{m}$.

8 nucleotide differences in 120 sites), Streptomyces niveus ISP $5088^{\mathrm{T}}(92.5 \%)$ and Streptomyces spheroides ISP $5292^{\mathrm{T}}$ $(91.7 \%)$ (see Supplementary Table A in IJSEM Online). The low DNA-DNA relatedness between strain YIM $001^{\mathrm{T}}$ and S. niveus ISP $5088^{\mathrm{T}}(13 \cdot 2 \%)$ and S. spheroides ISP $5292^{\mathrm{T}}$ $(17 \cdot 8 \%)$ also confirmed that they are different species.

$16 \mathrm{~S}$ rDNA sequence similarities between YIM $001^{\mathrm{T}}$ and Streptomyces type strains are shown in Supplementary Table B. It is clear from the phylogenetic tree that strain YIM $001^{\mathrm{T}}$ forms a single branch separate from other representatives of the genus Streptomyces (Fig. 2), notably from its nearest neighbour Streptomyces sampsonii ISP $5394^{\mathrm{T}}(97 \cdot 57 \%$ similarity; 37 nucleotide differences in 1521 sites) and the closely related species Streptomyces rutgersensis DSM $40077^{\mathrm{T}}(97 \cdot 56 \% ; 36 / 1476)$, Streptomyces gougerotii DSM $40324^{\mathrm{T}}(97 \cdot 49 \% ; 37 / 1476)$, Streptomyces tuirus DSM $40505^{\mathrm{T}}(97 \cdot 46 \% ; 37 / 1457)$, Streptomyces albidoflavus ISP $5445^{\mathrm{T}}(97 \cdot 43 \% ; 38 / 1478)$, Streptomyces coelicolor ISP $5233^{\mathrm{T}}(97 \cdot 43 \% ; 38 / 1478)$, Streptomyces odorifer ISP $5347^{\mathrm{T}}(97 \cdot 43 \% ; 38 / 1478)$, Streptomyces felleus ISP $5130^{\mathrm{T}}(97 \cdot 43 \% ; 38 / 1478)$, Streptomyces limosus ISP $5131^{\mathrm{T}}(97 \cdot 43 \% ; 38 / 1478)$ and Streptomyces canescens ISP

Table 1. Culture characteristics of strain $\mathrm{YIM} 001^{\top}$ on various media

\begin{tabular}{|llllll|}
\hline Medium & Growth & Sporulation & Diffusible pigment & & \multicolumn{2}{c|}{ Colony colour } \\
\cline { 4 - 6 } & & & & Aerial mycelium & Substrate mycelium \\
\hline Yeast-malt extract agar (ISP 2) & Good & Good & Deep yellow-brown & Pale yellow-grey & Deep grey-yellow-brown \\
Oatmeal agar (ISP 3) & Moderate & Moderate & Soft yellow-brown & Deep yellow-grey & Deep grey-yellow \\
Inorganic salts-starch agar (ISP 4) & Good & Good & Deep yellow-brown & Deep grey-yellow & Deep yellow \\
Glycerol-asparagine agar (ISP 5) & Moderate & Moderate & Light yellow & White & Yellow-white \\
Potato agar & Good & Good & Moderate olive-brown & Light yellow-grey & Moderate olive-brown \\
Nutrient agar & Moderate & Moderate & Pale yellow & White & Pale yellow \\
Czapek's agar & Good & Good & Moderate reddish-brown & Yellow-grey & Light grey-reddish \\
& & & & & \\
\end{tabular}


Table 2. Phenotypic properties that separate strain YIM $001^{\top}$ from related Streptomyces species

Strains: 1 , strain YIM $001^{\mathrm{T}} ; 2$, S. beijiangensis YIM $6^{\mathrm{T}} ; 3$, S. niveus ISP $5088^{\mathrm{T}} ; 4$, S. spheroides ISP $5292^{\mathrm{T}}$; 5, S. albidoflavus ISP $5445^{\mathrm{T}}$; 6 , S. coelicolor ISP $5233^{\mathrm{T}} ; 7$, S. odorifer ISP $5347^{\mathrm{T}} ; 8$, S. felleus ISP $5130^{\mathrm{T}}$; 9, S. limosus ISP $5131^{\mathrm{T}}$; 10, S. sampsonii ISP $5394^{\mathrm{T}}$; 11 , S. canescens ISP $5001^{\mathrm{T}}$; 12, S. gougerotii ISP $5324^{\mathrm{T}}$; 13, S. rutgersensis ISP $5077^{\mathrm{T}}$; 14, S. tuirus ISP $5505^{\mathrm{T}}$. All strains used D-xylose as a sole carbon source. V, Variable; ND, not detected. Data for reference strains were taken from Shirling \& Gottlieb (1968, 1972), Williams et al. (1983) and Li et al. (2002).

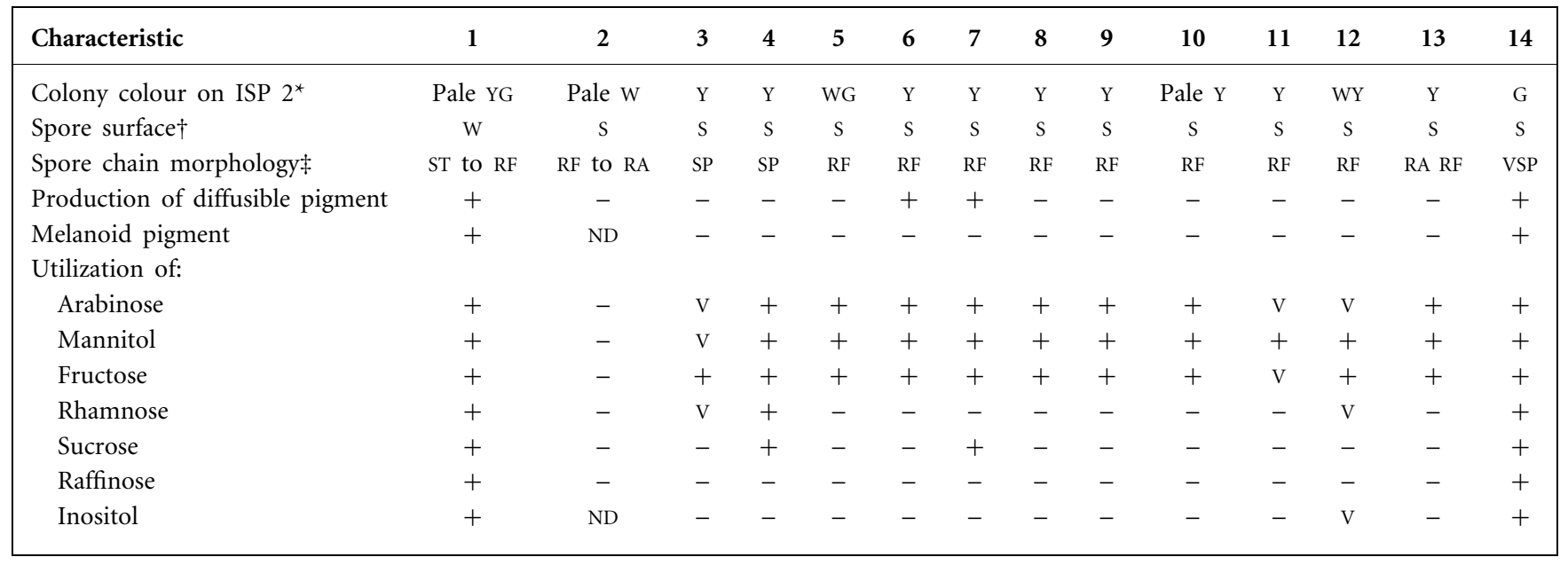

${ }^{*} \mathrm{G}$, Grey; W, white; WG, white-grey; wY, white-yellow; Y, yellow; YG, yellow-grey.

$\dagger \mathrm{W}$, Warty; s, smooth.

‡RA, Retinaculaperti; RF, Rectiflexibiles; SP, Spirales; ST, straight; vSP, verticillati and Spirales.

$5001^{\mathrm{T}}(97 \cdot 43 \% ; 38 / 1478)$. Strain YIM $001^{\mathrm{T}}$ can be readily distinguished from S. beijiangensis YIM $6^{\mathrm{T}}(95 \cdot 88 \%$; $61 / 1481$ ), which neighboured strain $\mathrm{YIM} 001^{\mathrm{T}}$ in the phylogenetic tree generated using $\gamma$-region sequences.

DNA-DNA hybridization studies were carried out between strain YIM $001^{\mathrm{T}}$ and closely related strains selected on the basis of their $16 \mathrm{~S}$ rDNA sequence similarity and phylogenetic positions. The low DNA-DNA relatedness between strain YIM $001^{\mathrm{T}}$ and S. sampsonii ISP $5394^{\mathrm{T}}(11 \cdot 7 \%), S$. rutgersensis DSM $40077^{\mathrm{T}}(21 \cdot 2 \%)$, S. gougerotii DSM $40324^{\mathrm{T}}(15 \cdot 3 \%)$, S. tuirus DSM $40505^{\mathrm{T}}(13 \cdot 2 \%)$, S. albidoflavus ISP $5445^{\mathrm{T}}(15 \cdot 2 \%)$, S. coelicolor ISP $5233^{\mathrm{T}}(8 \cdot 1 \%)$, S. odorifer ISP $5347^{\mathrm{T}}(17 \cdot 1 \%)$, S. felleus ISP $5130^{\mathrm{T}}(21 \cdot 3 \%)$, S. limosus ISP $5131^{\mathrm{T}}(9 \cdot 2 \%)$ and S. canescens ISP $5001^{\mathrm{T}}$ $(13.5 \%)$ confirmed that strain YIM $001^{\mathrm{T}}$ can be considered as a novel taxon. This is also supported by phenotypic data, as at least seven differences in phenotypic properties were observed between strain YIM $001^{\mathrm{T}}$ and its closest neighbours (Table 2). Comparison of the phenotypic characteristics of strain YIM $001^{\mathrm{T}}$ and S. tuirus reveals significant differences. Strain $\mathrm{YIM}_{000} 1^{\mathrm{T}}$ has straight to Rectiflexibiles spore chains, while S. tuirus has verticillati and Spirales spore chains. They can also be distinguished by colony colour and spore surface texture (Table 2).

In conclusion, the genotypic, chemotaxonomic and phenotypic data show that strain YIM $001^{\mathrm{T}}$ represents a novel species of the genus Streptomyces, for which we propose the name Streptomyces hebeiensis sp. nov.

\section{Description of Streptomyces hebeiensis sp. nov.}

Streptomyces hebeiensis (he.bei.en'sis. N.L. masc. adj. hebeiensis pertaining to Hebei, a province in northern China where the sample yielding the type strain was collected).

Grows well at 27,30 and $37^{\circ} \mathrm{C}$ but does not grow at 45 or $10^{\circ} \mathrm{C}$. Aerial mycelium and substrate mycelium are well developed. Aerial mycelium at maturity forms long, straight to Rectiflexibiles spore chains composed of nonmotile and coccoid spores with a warty surface. Diffusible pigments are produced on several media. The pigment(s) is not a $\mathrm{pH}$ indicator or is changed only slightly with addition of $0.05 \mathrm{M} \mathrm{HCl}$ in ISP 5 and ISP 6. Colony colour is medium-dependent (Table 1). In addition to the properties shown in Table 2, galactose, lactose, mannose, maltose, xylose, sorbitol, sodium citrate, sodium acetate, oxalate, starch and glycerol are utilized as sole carbon and energy sources, but cellulose and xylan are not. Acid is formed from mannose and starch but not from arabinose, fructose, galactose, glucose, inositol, lactose, mannitol, maltose, rhamnose, raffinose, sucrose, sorbitol, xylose, sodium citrate, sodium acetate, oxalate or glycerol. L-Histidine and L-hydroxyproline can be used as sole carbon and nitrogen sources. Casein and xanthine can be metabolized, but adenine and pectin can not. Tests for gelatin, nitrate reduction and melanin production are positive and tests for $\mathrm{H}_{2} \mathrm{~S}$ production, peptonization of milk are negative. Grows in the presence of 4 or $7 \% \mathrm{NaCl}$ 


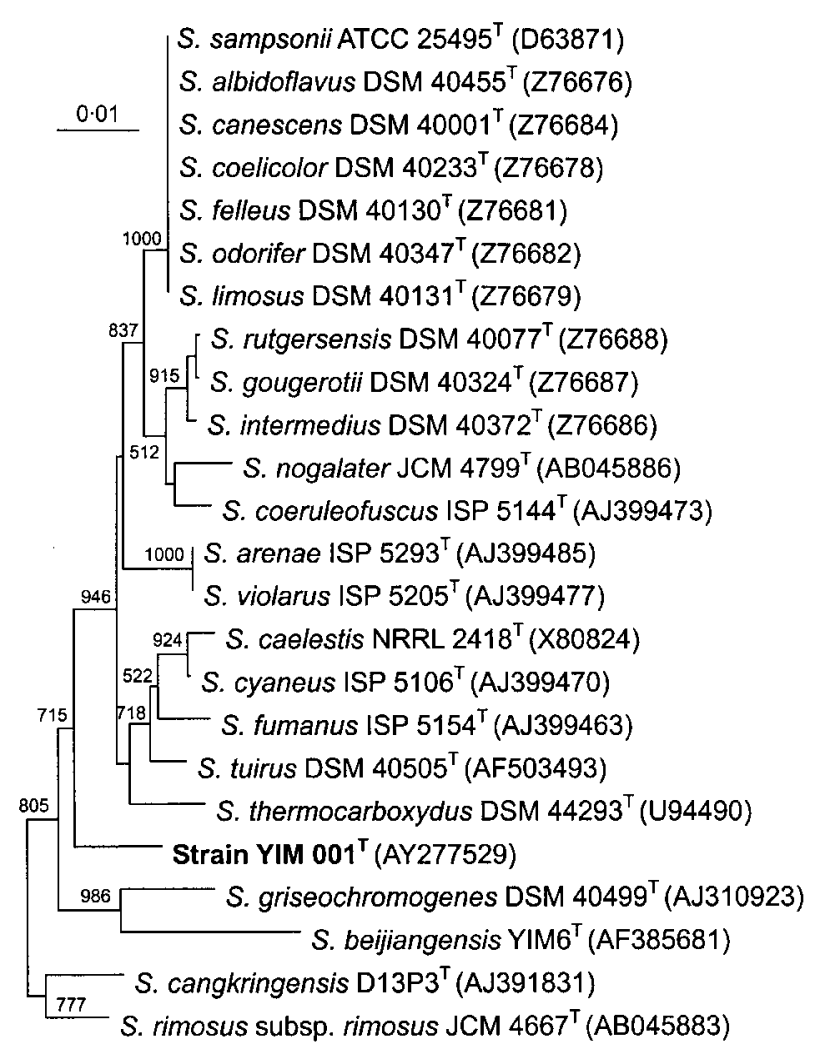

Fig. 2. Phylogenetic dendrogram obtained by neighbour-joining analysis based on 1443 bp of $16 \mathrm{~S}$ rDNA sequences, showing the position of strain $\mathrm{YIM} 001^{\top}$ among its phylogenetic neighbours. Numbers on branch nodes are bootstrap values (1000 resamplings). Sequence accession numbers are given in parentheses. The sequence of Actinoplanes philippinensis IFO $13878^{\top}$ (D85474) was used as the root. Bar, 0.01 substitutions per nucleotide position.

and $0 \cdot 1 \%$ phenol. Diagnostic amino acid of peptidoglycan is $\mathrm{LL}-\mathrm{A}_{2} \mathrm{pm}$ with trace amounts of meso- $\mathrm{A}_{2} \mathrm{pm}$. Whole-cell hydrolysates contain glucose and small quantities of xylose, galactose and arabinose. The menaquinones are $\mathrm{MK}-9\left(\mathrm{H}_{4}\right) \quad(4 \cdot 6 \%)$, MK-9 $\left(\mathrm{H}_{6}\right) \quad(60 \%), \mathrm{MK}-9\left(\mathrm{H}_{8}\right)$ $(30 \cdot 7 \%)$ and $\mathrm{MK}-9\left(\mathrm{H}_{10}\right)(4 \cdot 7 \%)$ and phosphatidylethanolamine is the diagnostic phospholipid. The $\mathrm{G}+\mathrm{C}$ content of the DNA is $71.4 \mathrm{~mol} \%$.

The type strain, strain YIM $001^{\mathrm{T}}\left(=\right.$ CCTCC AA $203005^{\mathrm{T}}=$ CIP $107974^{\mathrm{T}}=\mathrm{DSM} 41837^{\mathrm{T}}$ ), was isolated from a soil sample collected from Hebei Province, northern China.

\section{Acknowledgements}

This research was supported by the Ministry of Science and Technology, PR China (project no. 2001CCC00600), the National Natural Science Foundation of China (project no. 30270004), the Yunnan Provincial Natural Science Foundation (project no. 20001C001Q) and the Yunnan Education Commission Foundation (project nos 01111134 and 02QJ077).

\section{References}

Altschul, S. F., Madden, T. L., Schäffer, A. A., Zhang, J., Zhang, Z., Miller, W. \& Lipman, D. J. (1997). Gapped BLAST and PSI-BLAST: a new generation of protein database search programs. Nucleic Acids Res 25, 3389-3402.

Becker, B., Lechevalier, M. P. \& Lechevalier, H. A. (1965). Chemical composition of cell-wall preparation from strains of various form-genera of aerobic actinomycetes. Appl Microbiol 13, 236-243.

Bérdy, J. (1995). Are actinomycetes exhausted as a source of secondary metabolites? Biotechnologia 7-8, 13-34.

Chun, J., Youn, H.-D., Yim, Y.-I., Lee, H., Kim, M. Y., Hah, Y. C. \& Kang, S.-O. (1997). Streptomyces seoulensis sp. nov. Int J Syst Bacteriol 47, 492-498.

Collins, M. D., Pirouz, T., Goodfellow, M. \& Minnikin, D. E. (1977). Distribution of menaquinones in actinomycetes and corynebacteria. J Gen Microbiol 100, 221-230.

Cui, X.-L., Mao, P.-H., Zeng, M., Li, W.-J., Zhang, L.-P., Xu, L.-H. \& Jiang, C.-L. (2001). Streptimonospora salina gen. nov., sp. nov., a new member of the family Nocardiopsaceae. Int J Syst Evol Microbiol 51, 357-363.

De Ley, J., Cattoir, H. \& Reynaerts, A. (1970). The quantitative measurement of DNA hybridization from renaturation rates. Eur J Biochem 12, 133-142.

Felsenstein, J. (1985). Confidence limits on phylogenies: an approach using the bootstrap. Evolution 39, 783-791.

Gordon, R. E., Barnett, D. A., Handerhan, J. E. \& Pang, C. H.-N. (1974). Nocardia coeliaca, Nocardia autotrophica, and the nocardin strain. Int J Syst Bacteriol 24, 54-63.

Hayakawa, M. \& Nonomura, H. (1987). Humic acid-vitamin agar, a new medium for the selective isolation of soil actinomycetes. J Ferment Technol 65, 501-509.

Huß, V. A. R., Festl, H. \& Schleifer, K. H. (1983). Studies on the spectrophotometric determination of DNA hybridization from renaturation rates. Syst Appl Microbiol 4, 184-192.

Jiang, L. Y., Li, M. G., Li, W. J., Cui, X. L., Xu, L. H. \& Jiang, C. L. (2001). Study on the application of quantitative analysis of cell-wall amino acids in actinomycetes. Acta Microbiol Sin 41, 270-277.

Kelly, K. L. (1964). Color-name Charts Illustrated with Centroid Colors. Chicago: Inter-Society Color Council-National Bureau of Standards.

Kimura, M. (1980). A simple method for estimating evolutionary rates of base substitutions through comparative studies of nucleotide sequences. J Mol Evol 16, 111-120.

Labeda, D. P., Lechevalier, M. P. \& Testa, R. T. (1997). Streptomyces stramineus sp. nov., a new species of the verticillate streptomycetes. Int J Syst Bacteriol 47, 747-753.

Lechevalier, M. P. \& Lechevalier, H. A. (1980). The chemotaxonomy of actinomycetes. In Actinomycete Taxonomy, pp. 227-291. Edited by A. Dietz \& D. W. Thayer. Arlington, VA: Society for Industrial Microbiology.

Lechevalier, M. P., Stern, A. E. \& Lechevalier, H. A. (1981). Phospholipids in the taxonomy of actinomycetes. Zentbl Bakteriol Hyg 1 Abt Suppl 11, 111-116.

Li, W.-J., Zhang, L.-P., Xu, P., Cui, X.-L., Lu, Z.-T., Xu, L.-H. \& Jiang, C.-L. (2002). Streptomyces beijiangensis sp. nov., a psychrotolerant actinomycete isolated from soil in China. Int J Syst Evol Microbiol 52, 1695-1699.

Mandel, M. \& Marmur, J. (1968). Use of ultraviolet absorbance temperature profile for determining the guanine plus cytosine content of DNA. Methods Enzymol 12B, 195-206. 
Saitou, N. \& Nei, M. (1987). The neighbor-joining method: a new method for reconstructing phylogenetic trees. Mol Biol Evol 4, 406-425.

Shirling, E. B. \& Gottlieb, D. (1966). Methods for characterization of Streptomyces species. Int J Syst Bacteriol 16, 313-340.

Shirling, E. B. \& Gottlieb, D. (1968). Cooperative description of type cultures of Streptomyces. II. Species descriptions from first study. Int J Syst Bacteriol 18, 69-189.

Shirling, E. B. \& Gottlieb, D. (1972). Cooperative description of type cultures of Streptomyces. V. Additional descriptions. Int J Syst Bacteriol 22, 265-394.

Takeuchi, M. \& Hatano, K. (1998). Gordonia rhizosphera sp. nov. isolated from the mangrove rhizosphere. Int J Syst Bacteriol 48, 907-912.

Tatusova, T. A. \& Madden, T. L. (1999). BLAST 2 Sequences, a new tool for comparing protein and nucleotide sequences. FEMS Microbiol Lett 174, 247-250.
Thompson, J. D., Higgins, D. G. \& Gibson, T. J. (1994). CLUSTAL W: improving the sensitivity of progressive multiple sequence alignment through sequence weighting, position-specific gap penalties and weight matrix choice. Nucleic Acids Res 22, 4673-4680.

Waksman, S. A. \& Henrici, A. (1943). The nomenclature and classification of the actinomycetes. J Bacteriol 46, 337-341.

Williams, S. T., Goodfellow, M., Alderson, G., Wellington, E. M. H., Sneath, P. H. A. \& Sackin, M. J. (1983). Numerical classification of Streptomyces and related genera. J Gen Microbiol 129, 1743-1813.

Williams, S. T., Goodfellow, M. \& Alderson, G. (1989). Genus Streptomyces Waksman and Henrici 1943, 339 ${ }^{\mathrm{AL}}$. In Bergey's Manual of Systematic Bacteriology, vol. 4, pp. 2452-2492. Edited by S. T. Williams, M. E. Sharpe \& J. G. Holt. Baltimore: Williams \& Wilkins. 